OPEN ACCESS

Edited by:

Fanglei Zuo,

Karolinska Institutet, Sweden

Reviewed by:

Pasquale Russo,

University of Foggia, Italy

Zhu Zeng,

Southwest University, China

*Correspondence:

Kingsley Yin

yinki@rowan.edu

Specialty section:

This article was submitted to

Clinical Microbiology,

a section of the journal

Frontiers in Cellular and Infection

Microbiology

Received: 06 July 2021

Accepted: 24 August 2021

Published: 13 September 2021

Citation:

Wilson RM, Walker JM and Yin K (2021) Different Concentrations of Lactobacillus acidophilus Cell Free

Filtrate Have Differing Anti-Biofilm and Immunomodulatory Effects. Front. Cell. Infect. Microbiol. 11:737392.

doi: 10.3389/fcimb.2021.737392

\section{Different Concentrations of Lactobacillus acidophilus Cell Free Filtrate Have Differing Anti-Biofilm and Immunomodulatory Effects}

\author{
Rachael M. Wilson, Jean M. Walker and Kingsley Yin * \\ Department of Cell Biology and Neuroscience, Rowan University - School of Osteopathic Medicine, Stratford, NJ, United States
}

Probiotics such as various strains of Lactobacillaceae have been shown to have antimicrobial and immunomodulatory activity. In vitro studies have shown that Lactobacilli can decrease bacterial biofilm formation. Effects on immune cells have been unclear with most studies showing anti-inflammatory activity. The mechanism of effects has not been clearly elucidated. In these studies, we used different concentrations of live Lactobacillus acidophilus as well as cell free filtrate (CFF) derived from different concentrations of bacteria. Use of CFF is advantageous as a therapeutic because in vivo it can directly contact immune cells and its concentration is fixed. Both live cells and CFF inhibited Pseudomonas aeruginosa biofilm formation. Importantly, we show that high concentration CFF destroyed mature biofilm. This activity was not due to a lowered pH per se, as $\mathrm{pH}$ matched $\mathrm{HCl}$ did not remove mature biofilm. High concentration CFF totally inhibited $P$. aeruginosa growth and was bactericidal (>99.99\%), but low concentration CFF was not bactericidal. To examine the immunomodulatory effects of $L$. acidophilus, we incubated THP-1 monocytes and derived macrophages with CFF and measured TNF $\alpha$ production. CFF did not significantly increase TNF $\alpha$ production in THP-1 monocytes. When cells were prestimulated with LPS, high concentration CFF increased TNF $\alpha$ production even further. In macrophages, high concentration CFF alone increased TNF $\alpha$ production but did not affect LPS prestimulated cells. In contrast, low concentration CFF decreased TNF $\alpha$ production in LPS prestimulated cells. To elucidate the possible mechanisms for these effects, we repeated the experiments using a NF- $\mathrm{KB}$ reporter THP-1 cell line. High concentration CFF increased NF- $\kappa B$ activity in monocytes and macrophages. In LPS prestimulated macrophages, only low concentration CFF reduced NF- $\mathrm{KB}$ activity. These results suggest that high concentration $\mathrm{CFF}$ alone induced $\mathrm{NF}-\kappa \mathrm{B}$ expression which could account partially for an increase in TNF $\alpha$ production. On the other hand, in macrophages, the lower non-bactericidal concentration of CFF reduced $\mathrm{NF}-\mathrm{\kappa B}$ expression and decreased TNF $\alpha$ production after LPS prestimulation. Taken together, the results provide evidence that different concentrations of $L$. acidophilus CFF 
possess varying bactericidal, anti-biofilm and immunomodulatory effects. This is important in vivo to evaluate the possible use of $L$. acidophilus CFF in different conditions.

Keywords: biofilm, probiotics, postbiotics, macrophages, Pseudomonas aeruginosa, NF-кB

\section{INTRODUCTION}

Bacterial infections are extremely common in the community. The host responds to the infection when bacterial derived products such as lipopolysaccharide (LPS), lipoteichoic acid, peptidoglycans and lipoproteins, all of which possess pathogen associated molecular patterns (PAMPs), bind to pathogen recognition receptors (PRRs) on immune cells. This binding to PRRs on patrolling monocytes and/or tissue macrophages is a critical step in the activation of the innate immune system. The subsequent signaling activates leukocytes to release a large quantity of inflammatory mediators, including chemokines, cytokines, arachidonic acid metabolites, and free radicals. This inflammatory response helps clear bacteria, but if highly elevated, can cause tissue injury or organ failure (Angus and van der Poll, 2013). On the other hand, sustained inflammation may cause dysregulated immune response where the host is unable to clear pathogen (Hotchkiss et al., 2013). Therefore, it is imperative that host defense is stimulated to clear bacteria efficiently without excessive, prolonged activation. Antibiotics are the standard treatment modality for bacterial infections, but overuse of antibiotics can cause antibiotic resistance (Dodds, 2017). Importantly, bacteria have mechanisms such as biofilm formation which allows the bacteria to evade antibiotic action. Biofilm is composed of exopolysaccharides, nucleic acids and proteins that help encapsulate the bacteria and prevents antibiotics and/or host defense from attacking the bacteria (Davies et al., 1998; Costerton et al., 1999; Thornton et al., 2021). Expression of antibiotic resistance genes and/or biofilm formation increases bacterial virulence. In addition, antibiotics have little to no effect on host defense to promote bacteria clearance. Bacteriostatic chloramphenicol or erythromycin have been reported to decrease the innate immune system's ability to clear bacteria (Kristian et al., 2007). In an ideal situation, an antimicrobial would also be immunomodulatory, to clear bacteria in the most efficient manner.

$P$. aeruginosa is an opportunistic gram-negative bacterium which is of particular concern in immunocompromised patients (Gellatly and Hancock, 2013). The quorum sensing system is a coordinated pathway which increases the virulence of $P$. aeruginosa when the bacteria reach a critical population density. On activation of the quorum sensing system, the bacteria secrete specific autoinducing agents which when bound to their cognate receptors, activate the expression of many virulence genes responsible for the release of exotoxins (pyocyanin and elastase), biofilm formation and antibiotic resistance (Jimenez et al., 2012; Lee and Zhang, 2015).

Probiotics are non-pathogenic bacteria found in the gut microbiome which confer many health benefits on the host. Indeed, probiotics have been reported to have anti-inflammatory properties in rodent models of inflammatory bowel disease (Wang et al., 2020) and Citrobacter- induced colitis (Chen et al., 2009). Supplementation with probiotics has also been reported to have prophylactic benefits against burn wound infection (Argenta et al., 2016), increased survival after administration of multidrug-resistant $P$. aeruginosa (Machairas et al., 2015) and murine sepsis (Khailova et al., 2013). All these studies have administered the probiotic bacteria prophylactically as a pretreatment. These studies, therefore, did not provide information on the possibility of using probiotics as a therapeutic given after the onset of infection. Furthermore, studies are now focusing on postbiotics, which include the substances secreted by probiotic bacteria including proteins and organic acids (Maghsood et al., 2020; Zolkiewicz et al., 2020). In efforts to elucidate cellular mechanisms, studies using probiotics in vitro showed interesting results where incubation of macrophages with different Lactobacilli strains increased cytokine production (Rocha-Ramirez et al., 2017). It is important to note that for therapeutic purposes probiotics are administered orally. The non-pathogenic bacteria therefore are not in direct contact with immune cells. To confirm that probiotics had immunomodulatory effects, De Marco et al. (2018) incubated Lactobacilli cell free supernatants with human macrophages. In these studies using macrophages stimulated with LPS, the Lactobacilli appear to be antiinflammatory where probiotic addition decreased cytokine release (De Marco et al., 2018). Although these studies provide information on the actions of probiotics at the cellular level, they did not attempt to reconcile the differing results. Importantly, none of the aforementioned studies examined the effects of different concentrations of probiotics to investigate the concentration-dependence of the reported effects.

Apart from their effects on immune cells, several studies have reported that various probiotics have direct effects to reduce bacterial virulence. Lactobacilli isolated from oral cavities of healthy volunteers reduced biofilm formation and elastase activity (Alexandre et al., 2014). Lactoplantibacillus plantarum [L. plantarum; (Zheng et al., 2020)] was able to reduce the number of bacteria within human plasma biofilm (Besser et al., 2019). Similarly, a probiotic combination reduced the thickness of a bacterial-fungal polymicrobial biofilm (Hager et al., 2019). $L$. plantarum cell free supernatant reduced $P$. aeruginosa biofilm formation (Ramos et al., 2012). However, there is no work to elucidate if concentrations of probiotic that have cellular modulatory activities also have antimicrobial activity.

The objective of this study was to show that Lactobacillus acidophilus (L. acidophilus) is both antimicrobial and immunomodulatory. We designed experiments to study the in vitro effects of different concentrations of $L$. acidophilus on both monocyte/macrophage activation as well as $P$. aeruginosa growth 
and biofilm formation/removal. We focused our studies on the effects of cell free filtrates (CFF) derived from different concentrations of $L$. acidophilus bacteria. In addition, we used a NF- $\kappa$ B reporter THP-1 monocyte cell line to elucidate the mechanism by which $L$. acidophilus CFF modulates monocyte/ macrophage inflammatory activity.

\section{MATERIALS AND METHODS}

\section{Bacterial Strains and Cell Free Filtrate Preparation}

All bacterial strains as well as the THP-1 TIB-202 and THP-1 NF- $\kappa B-L U C 2$ cell lines were obtained from the American Type Culture Collection (Manassas, VA, USA). L. acidophilus ATCC $4356^{\mathrm{TM}}$ was cultivated in de Man, Rogosa and Sharpe (MRS) broth (Research Products International, Mt. Prospect, IL, USA) for $48 \mathrm{~h}$ at $37^{\circ} \mathrm{C}, 5 \% \mathrm{CO}_{2}$ as previously described (Khailova et al., 2013; Besser et al., 2019; Han et al., 2019; Maghsood et al., 2020). Prior to use in experiments, cultures were centrifuged at $1920 \mathrm{xg}$ for $6 \mathrm{~min}$. Culture supernatants were discarded and pellets were washed in M63 minimal medium (Amresco, Cleveland, $\mathrm{OH}$, USA) supplemented with $1 \mathrm{mM} \mathrm{MgSO}_{4}, 0.2 \%$ glucose, and $0.5 \%$ casamino acids (Fisher BioReagents, Pittsburgh, PA, USA) for a total of three washes. After the third wash, pellets were resuspended in M63 minimal medium. To confirm colony forming units (CFUs), cultures were diluted in sterile saline (Molecular Biologicals International, Irvine, CA, USA), spread onto MRS agar plates, incubated for $48 \mathrm{~h}$ at $37^{\circ} \mathrm{C}, 5 \% \mathrm{CO}_{2}$, and colonies counted.

The following preparations of L. acidophilus were used: 1) L. acidophilus $10^{6} \mathrm{CFU} / 200 \mu \mathrm{L}, 10^{7} \mathrm{CFU} / 200 \mu \mathrm{L}$ or $10^{8} \mathrm{CFU} / 200 \mu \mathrm{L}$ $\left(10^{6}-10^{8} \mathrm{CFU} / 200 \mu \mathrm{L}\right)$ suspended in M63 minimal medium to prepare whole cell suspensions (WCS). 2) To obtain an equivalent CFF, L. acidophilus at low, mid, and high concentrations $\left(10^{6}-10^{8} \mathrm{CFU} / 200 \mu \mathrm{L}\right)$ was cultured for $6 \mathrm{~h}$ and then centrifuged at $1920 \mathrm{x} \mathrm{g}$ for $6 \mathrm{~min}$. The supernatants were then filtered through a $0.22 \mu \mathrm{m}$ filter (Pall Corporation, Port Washington, NY, USA). We have data which show that MRS media by itself may inhibit biofilm formation (Supplemental Data; Figure S1). In our studies, we used a specific quantity of $L$. acidophilus incubated in the same media (M63 minimal medium) as the $P$. aeruginosa for a precise amount of time to obtain cell free filtrate. This methodology affords us the ability to interrogate the pharmacological potency of the CFF.

$P$. aeruginosa ATCC $27853^{\mathrm{TM}}$ was grown on Tryptic soy agar (TSA; Ward's Scientific, Rochester, NY, USA) overnight at $37^{\circ} \mathrm{C}$. Liquid cultures were inoculated by depositing $P$. aeruginosa colonies into Luria-Bertani broth (Gibco: Gaithersburg, MD, USA). The cultures were incubated for $5 \mathrm{~h}$ at $37^{\circ} \mathrm{C}$ with shaking $(180 \mathrm{rpm})$ and then centrifuged for $6 \mathrm{~min}$ at $9100 \mathrm{x}$ g. Culture supernatants were removed and pellets were washed three times in M63 minimal medium to promote biofilm formation (Musafer et al., 2014; Mattingly et al., 2018; Wijesinghe et al., 2019; Bullock et al., 2020; Quintieri et al., 2020). The cultures were diluted in
M63 minimal medium to $\mathrm{OD}_{600}$ between 0.04 - 0.06 using a BioTek Synergy H1 plate reader (Biotek, Winooski, VT, USA). Our studies used M63 minimal medium at pH 5.5 to recapitulate various disease environments that $P$. aeruginosa has been reported to persist in, including on the protective skin barrier (Bullock et al., 2020) and in airways of cystic fibrosis patients (Moriarty et al., 2007).

Escherichia coli ATCC BAA-1883 ${ }^{\mathrm{TM}}$ was grown in Tryptic soy broth (TSB; Sigma-Aldrich, St. Louis, MO, USA) for $24 \mathrm{~h}$ at $37^{\circ} \mathrm{C}$. The cultures were centrifuged for $6 \mathrm{~min}$ at $9100 \mathrm{x}$ g. The culture supernatants were removed and the pellet was washed three times in TSB to remove any culture virulence factors. The culture was then diluted in TSB to $\mathrm{OD}_{600} 0.06$ for planktonic growth studies described below.

\section{Biofilm Formation Assay}

$P$. aeruginosa adjusted to $\mathrm{OD}_{600} 0.04$ was prepared as described above and inoculated into a round-bottom 96-well plate. $100 \mu \mathrm{L}$ of $L$. acidophilus $\left(10^{6}-10^{8} \mathrm{CFU} / 200 \mu \mathrm{L}\right) \mathrm{WCS}$ or CFF was added together with $100 \mu \mathrm{L}$ of M63 media making a 50\% CFF solution. Each treatment group was performed in quintuplicate. The plate was incubated for $24 \mathrm{~h}$ at $37^{\circ} \mathrm{C}$. To measure biofilm formation, the plates were washed in phosphate buffered saline (PBS; Growcells, Irvine, CA, USA) three times to remove nonadherent cells. $200 \mu \mathrm{L}$ of $0.1 \%$ crystal violet in ddH20 (SigmaAldrich, St. Louis, MO, USA) was added to each well for $15 \mathrm{~min}$. The plates were washed three times in PBS to remove excess crystal violet stain and dried overnight. $200 \mu \mathrm{L}$ of modified biofilm dissolving solution (10\% SDS dissolved in $80 \%$ ethanol) (Tram et al., 2013) was added to each well for $15 \mathrm{~min}$. The dissolved biofilm solution was transferred to a flat-bottom 96-well plate and $\mathrm{OD}_{600}$ was measured.

\section{Established Biofilm Assay}

To study the effects of L. acidophilus WCS or CFF on established biofilm, $P$. aeruginosa biofilms were grown undisturbed for $20 \mathrm{~h}$ or $48 \mathrm{~h}$. After incubation, the plates were washed as described above and the biofilms were exposed to M63 media, L. acidophilus $\left(10^{6}-10^{8} \mathrm{CFU} / 200 \mu \mathrm{L}\right) \mathrm{WCS}$ or CFF for $1 \mathrm{~h}$ or $6 \mathrm{~h}$. We investigated if acidity per se caused the anti-biofilm effects observed. $200 \mu \mathrm{L}$ of $\mathrm{HCl} \mathrm{pH}$-matched to L. acidophilus $10^{8}$ $\mathrm{CFU} / 200 \mu \mathrm{L}$ and $10^{6} \mathrm{CFU} / 200 \mu \mathrm{L}$ CFF (pH 4 and $\mathrm{pH} 5$ ) were used. In addition, to determine if a protein within the CFF was responsible for biofilm removal, the CFF was boiled $\left(100^{\circ} \mathrm{C}\right)$ for $15 \mathrm{~min}$ to denature proteins and $200 \mu \mathrm{L}$ was added to the wells for $6 \mathrm{~h}$. To further investigate protein activity on biofilm removal, $100 \mu \mathrm{g} / \mathrm{mL}$ Proteinase K (Promega, Madison, WI, USA), a broad spectrum serine protease, was reconstituted in $50 \mathrm{mM}$ Tris-HCl (Sigma-Aldrich, St. Louis, MO, USA), $10 \mathrm{mM}$ $\mathrm{CaCl}_{2}$ (Fisher Scientific, Fair Lawn, NJ, USA) and added to the CFF for $1 \mathrm{~h}$ at $37^{\circ} \mathrm{C}$ prior to use in experiments. To inhibit protease activity, $1 \mathrm{mM}$ phenylmethylsulfonyl fluoride (PMSF; Bio Basic, Markham, ON, Canada) was added and $200 \mu \mathrm{L}$ protein digested CFF was added to the well for $6 \mathrm{~h}$. Following treatment incubations, the biofilm biomass was quantified with crystal violet as in biofilm formation assays. 


\section{Planktonic Growth Curves and Bactericidal Activity}

$P$. aeruginosa and E. coli were prepared as described above. For planktonic growth curve experiments, $100 \mu \mathrm{L}$ of $P$. aeruginosa or E. coli adjusted to $\mathrm{OD}_{600} 0.06$ was added to a flat-bottom 96-well plate. $100 \mu \mathrm{L}$ of CFF derived from L. acidophilus $\left(10^{6}-10^{8} \mathrm{CFU} /\right.$ $200 \mu \mathrm{L}$ ) was added to wells. M63 media was added to make a final volume of $200 \mu \mathrm{L}$. This is a $50 \%$ CFF solution derived from each quantity of $L$. acidophilus bacteria. To examine if low $\mathrm{pH}$ had a significant effect on growth, $100 \mu \mathrm{L} \mathrm{HCl} \mathrm{pH-matched} \mathrm{to} \mathrm{the} L$. acidophilus $10^{8} \mathrm{CFF}(\mathrm{pH} 4)$ was used in separate wells. In addition, we utilized $1 \mu \mathrm{g} / \mathrm{mL}$ ciprofloxacin (Enzo, Farmingdale, NY, USA) as positive control. The plate reader was set to $37^{\circ} \mathrm{C}$ with orbital shaking and programmed to measure $\mathrm{OD}_{600}$ every $10 \mathrm{~min}$ for $20 \mathrm{~h}$. Following the absorbance measurements, cultures from two wells of each group were recovered and serially diluted in saline. $100 \mu \mathrm{L}$ of each dilution was spread onto TSA, incubated overnight at $37^{\circ} \mathrm{C}$, and colonies counted.

\section{Inflammatory Mediator Assay}

THP-1 (ATCC TIB-202 ${ }^{\mathrm{TM}}$ ) monocytes were cultured and maintained in RPMI 1640 with L-glutamine (Corning, Manassas, VA, USA) supplemented with $10 \%$ heat-inactivated fetal bovine serum (FBS; Corning, Manassas, VA, USA), 0.05 mM 2-mercaptoethanol (VWR, Solon, OH, USA), and $100 \mathrm{U} /$ $\mathrm{mL}$ penicillin $\mathrm{G}, 100 \mu \mathrm{g} / \mathrm{mL}$ streptomycin (VWR, Solon, $\mathrm{OH}$, USA) at $37^{\circ} \mathrm{C}, 5 \% \mathrm{CO}_{2}$. To evaluate the effects of L. acidophilus CFF on TNF $\alpha$ production, THP-1 monocytes were seeded at $3 \times 10^{5}$ cells/well in 24-well plates in serum-free and pen-strep free RPMI and incubated overnight. To stimulate TNF $\alpha$ secretion, 50 $\mathrm{ng} / \mathrm{mL}$ of E. coli O111:B4 Lipopolysaccharide (LPS; EMD Millipore Corp., Billerica, MA, USA) was added for $1 \mathrm{~h}$ prior to the addition of $50 \mu \mathrm{L} \mathrm{L}$. acidophilus CFF (5\% solution) overnight treatment. The cell culture supernatants were collected and stored at $-70^{\circ} \mathrm{C}$. The levels of TNF $\alpha$ production were also measured in THP-1 monocyte-derived macrophages. Macrophage differentiation was achieved by stimulating THP-1 monocytes with $100 \mathrm{ng} / \mathrm{mL}$ phorbol 12-myristate 13-acetate (PMA; Sigma-Aldrich, St. Louis, MO, USA) for $48 \mathrm{~h}$. After differentiation, the media was aspirated and the cells were washed with saline three times. Serum-free and pen/strep- free media was replenished. Following a $24 \mathrm{~h}$ rest, the cells were washed with saline and then stimulated with LPS (50 ng/ml) $1 \mathrm{~h}$ prior to L. acidophilus CFF treatment. THP-1 monocyte and THP-1 monocyte-derived macrophages cell culture supernatants were analyzed for TNF $\alpha$ by ELISA (ELISA; Invitrogen, Carlsbad, CA, USA) according to the manufacturer's protocols.

\section{NF- $\kappa B$ Activation Assay}

To elucidate the cellular mechanism by which the L. acidophilus CFF alters TNF $\alpha$ production, the THP-1 NF- $\kappa B-L U C 2$ (ATCC TIB-202-NFKB-LUC2 ${ }^{\mathrm{TM}}$ ) cell line was used. Here, the firefly luciferase gene, luc2 was placed under the control of the NF$\kappa \mathrm{B}$ promoter such that NF- $\kappa \mathrm{B}$ activation could be measured via luciferase luminescence. THP-1 NF-אB-LUC2 monocytes and macrophages were cultured in 96-well plates, activated with LPS, and treated with $L$. acidophilus $\mathrm{CFF}$ as described in inflammatory mediator assays. In separate experiments, THP-1 NF- $\kappa B-L U C 2$ monocytes were differentiated into macrophages using the methodology noted above. Following overnight treatments, Firefly Luc One-Step Glow Assay Kit (Pierce, Rockford, IL, USA) was used as per the manufacturer's protocol. Briefly, the cells were lysed and incubated with D-Luciferin substrate for 15 min. The Biotek Synergy H1 plate reader was programmed to measure luminescence with an integration time of $1 \mathrm{sec}$ at 135 gain. In addition, THP-1 monocytes not expressing luc2 were used as negative controls (Supplemental Data; Figure S2). To validate the assay, QuantiLum Recombinant Luciferase (Promega, Madison, WI, USA) in Firefly Luc One-Step assay buffer (Pierce, Rockford, IL, USA) with 1\% bovine serum albumin (BSA; BioVision, Milpitas, CA, USA) was serially diluted and luminescence measured every $5 \mathrm{~min}$ for a $30 \mathrm{~min}$ period (Supplemental Data; Figure S2).

\section{Statistical Analyses}

All data are presented as mean \pm s. e. m. and all statistical computations were conducted using GraphPad Prism (San Diego, CA, USA). The area under curves were calculated for planktonic growth curves and statistical significance between groups was tested using one-way ANOVA and Tukey's multiple comparisons test. For all other studies, data were subjected to one-way ANOVA and Dunnett's test was used to identify the significance compared to appropriate media controls or LPS stimulated controls. In all statistical analyses, $\mathrm{P}<0.05$ was regarded as significant.

\section{RESULTS}

\section{L. acidophilus Reduces Biofilm Formation}

$P$. aeruginosa was incubated in M63 media with L. acidophilus WCS $\left(10^{6}-10^{8} \mathrm{CFU} / 200 \mu \mathrm{L}\right)$, CFF (50\% solution as described in Methods) or without any treatment (control) for $24 \mathrm{~h}$. Biofilm biomass was then quantitated by crystal violet staining. Both $L$. acidophilus WCS and CFF decreased biofilm formation in a concentration -dependent manner (Figure 1). The highest concentrations of L. acidophilus WCS and CFF reduced biofilm formation by more than $90 \%$ (Figure 1). The lowest concentration of CFF derived from $10^{6} \mathrm{CFU} / 200 \mu \mathrm{L}$ reduced biofilm formation by approximately $40 \%$, which was similar to WCS. These studies provide evidence that cell to cell contact is not necessary for anti-biofilm activity.

\section{L. acidophilus Removes Established Biofilm}

$P$. aeruginosa was allowed to mature for $20 \mathrm{~h}$. After the supernatant was removed and wells washed, WCS $\left(10^{6}-10^{8}\right.$ CFU/200 $\mu \mathrm{L}$ ), $200 \mu \mathrm{L}$ CFF or M63 media was added for $6 \mathrm{~h}$ before the remaining biofilm was quantitated. In these experiments we reasoned that it would be more difficult to remove established biofilm compared to stopping its formation, so we used $100 \%$ 

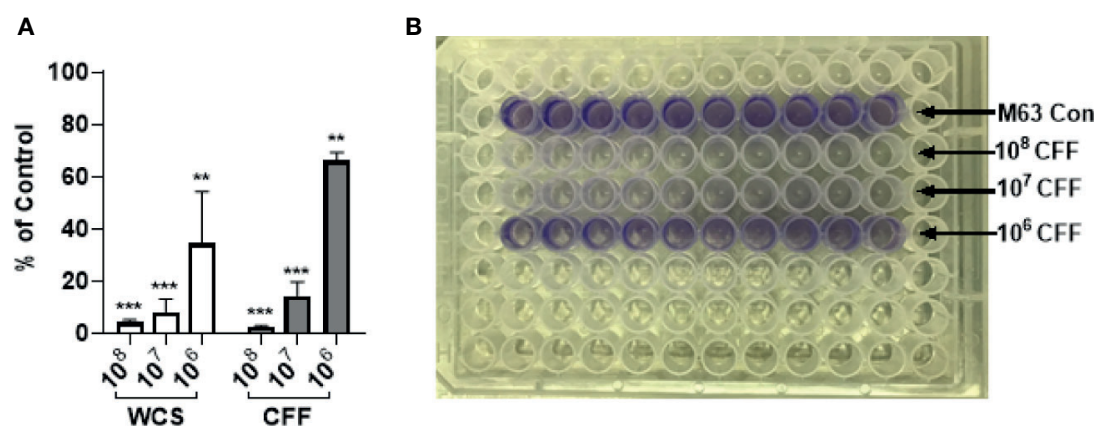

FIGURE 1 | L. acidophilus whole cell suspension (WCS) and cell free filtrate (CFF) inhibited $P$. aeruginosa biofilm formation. $P$. aeruginosa cultures were incubated with $L$. acidophilus $10^{6}-10^{8} \mathrm{CFU} / 200 \mu \mathrm{L}$ WCS or CFF at $37^{\circ} \mathrm{C}$ for $24 \mathrm{~h}$. Apical biofilms were stained with $0.1 \% \mathrm{crystal}$ violet and absorbance $\left(\mathrm{OD}_{600}\right)$ was measured to quantify biofilm formation. (A) All three concentrations of L. acidophilus WCS significantly reduced biofilm formation in a concentration-dependent manner. Similarly, all CFF concentrations significantly prevented biofilm formation and demonstrated a dose response. (B) Corresponding image of crystal violet stained 96-well plate at the end of biofilm formation experiment. Biofilm data are mean \pm s.e.m. percent change from control. ${ }^{* \star} p<0.01$, ${ }^{* \star \star} p<0.001 ;$ WCS $n=5$ independent experiments; CFF $\mathrm{n}=3$ independent experiments.

CFF instead of $50 \%$ CFF. WCS at concentrations of $10^{7}$ and $10^{8}$ $\mathrm{CFU} / 200 \mu \mathrm{L}$ significantly removed $20 \mathrm{~h}$ established biofilm but $10^{6} \mathrm{CFU} / 200 \mu \mathrm{L}$ did not have a significant effect (Figure 2A). All concentrations of CFF removed significant amounts of biofilm. In further experiments, we only used CFF as these studies provided evidence that CFF had similar and even better antibiofilm activity compared to whole cell suspensions. In separate studies, $P$. aeruginosa was allowed to form biofilm for $48 \mathrm{~h}$. Different concentrations of CFF were added to the established biofilm and incubated for $1 \mathrm{~h}$ and $6 \mathrm{~h}$ before the amount of
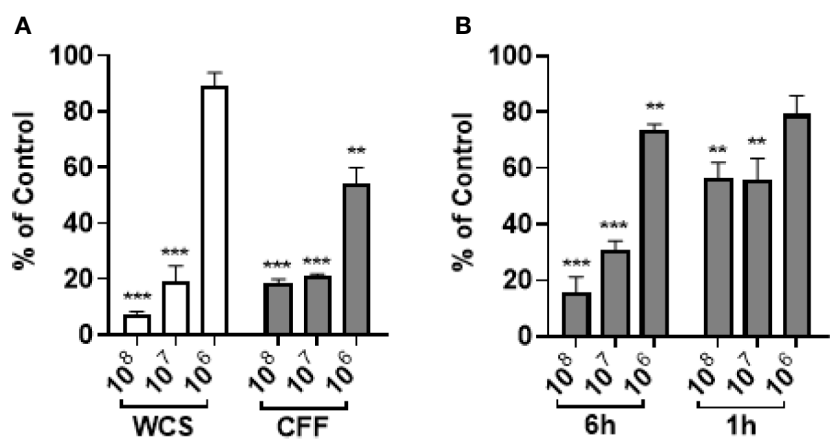

FIGURE 2 | L. acidophilus whole cell suspension (WCS) and cell free filtrate (CFF) removed $20 \mathrm{~h}$ and $48 \mathrm{~h}$ established $P$. aeruginosa biofilm. $P$. aeruginosa was incubated at $37^{\circ} \mathrm{C}$ for $20 \mathrm{~h}$ or $48 \mathrm{~h}$ prior to treatment with $\mathrm{L}$. acidophilus WCS or CFF for $1 \mathrm{~h}$ or $6 \mathrm{~h}$. The remaining biofilm was stained with $0.1 \%$ crystal violet and $\mathrm{OD}_{600}$ was measured. (A) After $6 \mathrm{~h}$ treatment, $10^{8}$ and $10^{7} \mathrm{CFU} / 200$ $\mu \mathrm{L}$ WCS significantly removed $20 \mathrm{~h}$ established biofilm, but $10^{6} \mathrm{CFU} / 200 \mu \mathrm{L}$ WCS did not. However, all concentrations of CFF significantly abolished $20 \mathrm{~h}$ biofilm, though $10^{6} \mathrm{CFF}$ was less effective. (B) Following $6 \mathrm{~h}$ treatment, all three concentrations of $L$. acidophilus CFF reduced 48 h established $P$. aeruginosa biofilm. Only $10^{8}$ and $10^{7} \mathrm{CFF}$ treatments significantly removed $48 \mathrm{~h}$ biofilm after $1 \mathrm{~h}$ treatment. Data are mean \pm s.e.m. percent change from control. ${ }^{* *} \mathrm{p}<$ $0.01,{ }^{\star \star \star} p<0.001$; WCS $n=3$ independent experiments $(20 \mathrm{~h}$ biofilm, $6 \mathrm{~h}$ treatment); CFF $\mathrm{n}=5$ independent experiments ( $20 \mathrm{~h}$ biofilm, $6 \mathrm{~h}$ treatment); CFF $\mathrm{n}=3$ independent experiments (48 $\mathrm{h}$ biofilm, $1 \mathrm{~h}$ and $6 \mathrm{~h}$ treatments). biofilm remaining was measured. After only $1 \mathrm{~h}, 10^{7}$ and $10^{8} \mathrm{CFF}$ were able to remove a significant amount of biofilm (Figure 2B). After $6 \mathrm{~h}, 10^{7}$ and $10^{8} \mathrm{CFF}$ reduced biofilm even further than after only $1 \mathrm{~h}$ incubation providing evidence of the time dependence of CFF anti-biofilm activity.

\section{Anti-Biofilm Effects of $L$. acidophilus Are Not Due to Lower pH Per Se}

In these studies, $\mathrm{HCl}$ and acetic acid solutions of $\mathrm{pH} 4$ and 5 were incubated with $20 \mathrm{~h}$ established biofilms for $6 \mathrm{~h}$. In other wells, established biofilms were also incubated with $100 \%$ CFF. Figure 3A shows that $\mathrm{HCl}$ of $\mathrm{pH} 4$ or 5 did not affect established biofilm. However, acetic acid of $\mathrm{pH} 4$ and $\mathrm{pH} 5$ significantly removed biofilm. In other experiments, the CFF was heated to $100^{\circ} \mathrm{C}$ for 15 min before incubations. The boiled high concentration CFF was still able to remove a significant amount of established biofilm but the lower concentration CFF was not able to remove a significant amount of pre-formed biofilm (Figure 3B). In addition, similar studies utilized Proteinase K, a serine protease, to confirm that proteins within the CFF were not solely responsible for the anti-biofilm effects. Figure 3C shows that CFF digested with Proteinase $\mathrm{K}$ retains most of its ability to significantly abolish $P$. aeruginosa established biofilm. Taken together, these data indicate that a large protein within the CFF is only partially responsible for the observed antibiofilm effects.

\section{$L$. acidophilus CFF inhibits $P$. aeruginosa Growth and Is Bactericidal}

To test if L. acidophilus CFF had direct antimicrobial activity against planktonic bacteria, $P$. aeruginosa or $E$. coli were incubated with CFF (50\%) derived from $10^{6}$ and $10^{8} \mathrm{CFU} / 200 \mu \mathrm{L}$ L. acidophilus or appropriate controls for $20 \mathrm{~h}$ with shaking. At the end of studies, bacteria remaining in the wells were spread on TSA plates. Figure $4 \mathrm{~A}$ shows that high concentration CFF (50\% solution) completely inhibited growth of $P$. aeruginosa (Figure 4A). To confirm that the high concentration CFF was bactericidal we 

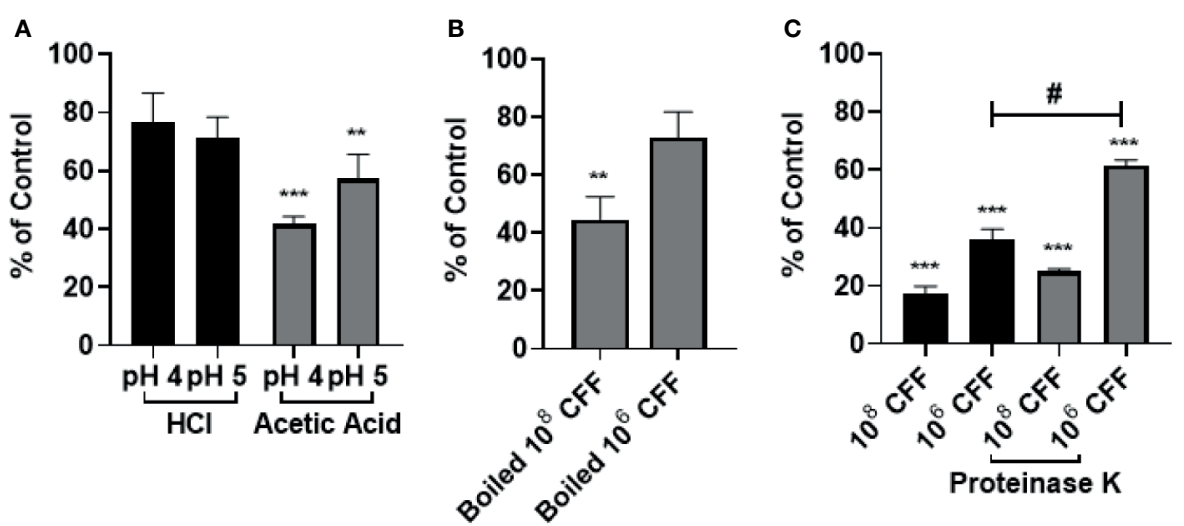

FIGURE 3 | The anti-biofilm effects of $L$. acidophilus cell free filtrate (CFF) were not due to acidity per se. (A) $\mathrm{HCl}$ and acetic acid pH matched to $10^{8}$ and $10^{6} \mathrm{CFF}$ $(\mathrm{pH} 4$ and 5, respectively), was added to $20 \mathrm{~h}$ established biofilm for $6 \mathrm{~h} \mathrm{HCl}$ did not reduce $P$. aeruginosa biofilm at either $\mathrm{pH}$ tested. Acetic acid (pH 4 and $\mathrm{pH} 5)$ removed approximately $60 \%$ and $40 \%$ of $20 \mathrm{~h}$ established biofilm. (B) L. acidophilus $10^{8}$ and $10^{6} \mathrm{CFF}$ was boiled at $100^{\circ} \mathrm{C}$ for 15 min to denature proteins. The boiled CFF was added to $20 \mathrm{~h}$ established biofilm for $6 \mathrm{~h} .10^{8}$ boiled CFF significantly reduced established biofilm but $10^{6} \mathrm{CFF}$ did not. (C) $100 \mathrm{\mu g} / \mathrm{mL}$ Proteinase $\mathrm{K}$ was added to the CFF at $37^{\circ} \mathrm{C}$ for $1 \mathrm{~h}$ and then inhibited with $1 \mathrm{mM}$ PSMF. The protein digested CFF was added to $20 \mathrm{~h} P$. aeruginosa biofilm for $6 \mathrm{~h}$. Both concentrations of CFF digested with Proteinase K significantly removed $20 \mathrm{~h}$ P. aeruginosa biofilm. With low concentration CFF however, Proteinase K reduced the anti-biofilm activity of the CFF. Data are mean \pm s.e.m. of percent from control. ${ }^{* *} \mathrm{p}<0.01,{ }^{* \star *} \mathrm{p}<0.001$ compared to control; ${ }^{*} \mathrm{p}<0.05$ compared to $10^{8} \mathrm{CFF}$ control; $\mathrm{HCl}$ and acetic acid $\mathrm{n}=4$ independent experiments; boiled CFF $\mathrm{n}=3$ independent experiments; Proteinase $\mathrm{K} n=4$ independent experiments.

A

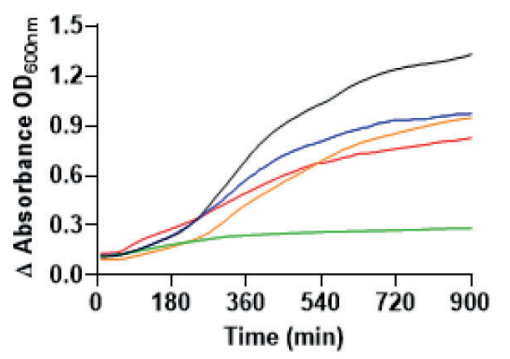

C

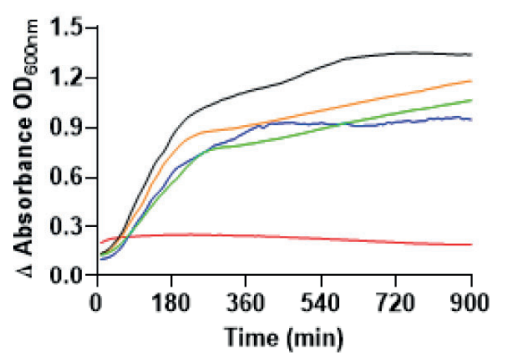

B
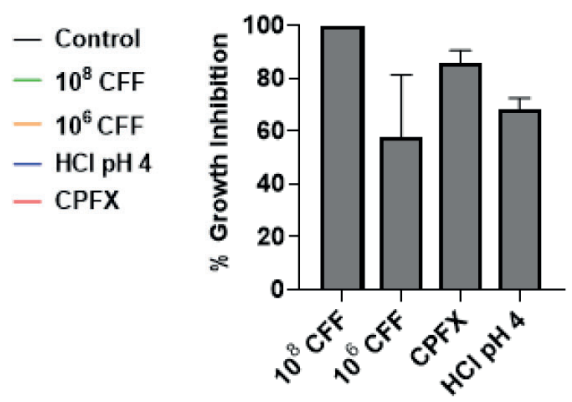

D

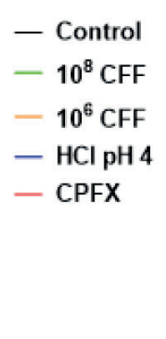

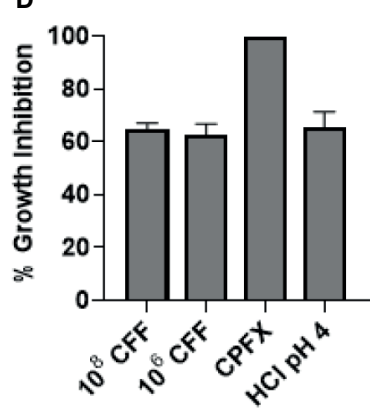

FIGURE 4 | L. acidophilus cell free filtrate (CFF) exhibits bactericidal action on P. aeruginosa planktonic cell growth but not on E. coli growth. Growth curves were conducted by incubating $P$. aeruginosa or $E$. coli in a 96-well plate with $L$. acidophilus $10^{8}$ or $10^{6} \mathrm{CFF}, 1 \mu \mathrm{g} / \mathrm{mL}$ ciprofloxacin (CPFX), or $\mathrm{HCl} \mathrm{pH} 4$ at $37^{\circ} \mathrm{C}$ with orbital shaking. Absorbance $\left(\mathrm{OD}_{600}\right)$ was measured every $10 \mathrm{~min}$ for $20 \mathrm{~h}$. (A) L. acidophilus $10^{8} \mathrm{CFF}$ completely inhibited $P$. aeruginosa planktonic growth $(\mathrm{p}<0.001) .10^{6} \mathrm{CFF}, \mathrm{HCl} \mathrm{pH} 4$, and $1 \mu \mathrm{g} / \mathrm{mL}$ ciprofloxacin affected $P$. aeruginosa growth, although significantly less effective than $10^{8} \mathrm{CFF}$. (B) At the end of growth curve studies, bacteria were spread on TSA plates and colonies counted. $10^{8}$ CFF killed $>99.99 \%$ P. aeruginosa and therefore was bactericidal. However, all other treatments were not bactericidal. (C) Both concentrations of $L$. acidophilus CFF and $\mathrm{HCl} \mathrm{pH} 4$ did not significantly inhibit $E$ coli growth. However, $1 \mu \mathrm{g} / \mathrm{mL}$ ciprofloxacin inhibited $E$. coli growth $(\mathrm{p}<0.001)$. (D) Following growth curve studies, E. coli cells were spread on TSA plates and colonies counted. Only $1 \mu \mathrm{g} / \mathrm{mL}$ ciprofloxacin was bactericidal $(>99.99 \%$ inhibition). P. aeruginosa growth curves $n=5$ independent experiments; $P$. aeruginosa CFUs $n=3$ independent experiments; $E$. coli growth curves $n=4$ independent experiments; $E$. coli CFUs $n=3$ independent experiments. 
spread the remaining bacteria on TSA plates. High concentration CFF was completely bactericidal where more than $99.99 \%$ of bacteria were killed (Figure 4B). Low concentration CFF only partially inhibited growth and was not bactericidal. Under these conditions, $1 \mu \mathrm{g} / \mathrm{ml}$ ciprofloxacin substantially inhibited growth of $P$. aeruginosa but was not bactericidal. In contrast, ciprofloxacin completely inhibited E. coli growth and was bactericidal but all concentrations of CFF were not bactericidal towards E. coli (Figures 4C, D). These results suggest that antimicrobial activity of $L$. acidophilus is species specific.

\section{L. acidophilus CFF Modulates Monocyte/ Macrophage Activity}

In these studies, we investigated the immunomodulatory effects of L. acidophilus CFF on THP-1 monocytes and THP-1 derived macrophages in vitro. As these are mammalian cells which can only grow at a narrow range of $\mathrm{pH}$ and temperature, we reasoned that it was imperative to keep the percentage concentration of the CFF solution low. Therefore, for these experiments, CFF percentage solution was 5\%. L. acidophilus CFF derived from $10^{6}$ and $10^{8} \mathrm{CFU} / 200 \mu \mathrm{L}$, was incubated with THP-1 monocytes or THP-1 derived macrophages for $20 \mathrm{~h}$. Supernatant was removed for measurement of TNF $\alpha$. CFF alone did not induce detectable amounts of TNF $\alpha$ (results not shown). In further studies, THP-1 monocytes were stimulated with $50 \mathrm{ng} / \mathrm{ml}$ LPS for $1 \mathrm{~h}$ before CFF was added. In THP-1 monocytes, LPS caused an increase in TNF $\alpha$ and addition of high concentration CFF increased TNF $\alpha$ further but low concentration CFF had no effect (Figure 5A). In THP-1 derived macrophages, high concentration CFF alone significantly increased production of TNF $\alpha$ (Figure 5B). When cells were first stimulated with LPS for $1 \mathrm{~h}$, low concentration CFF significantly reduced TNF $\alpha$ production (Figure 5C).

\section{L. acidophilus CFF Modulates NF- $\mathrm{kB}$ Activity in Monocytes/Macrophages}

In these studies, we repeated the previously described experiments using a luciferase NF- $\mathrm{KB}$ reporter THP-1 cell line to try to elucidate if $\mathrm{NF}-\mathrm{\kappa B}$ was involved in the L. acidophilus mediated changes in TNF $\alpha$ production. High concentration CFF increased NF- $\kappa$ B activity in THP-1 monocytes as well as macrophages (Figures 6A, C). Low concentration CFF alone had no effect on either cell type. After LPS stimulation, high concentration CFF had no significant effect on NF- $\kappa B$ activity in either cell type but low concentration CFF significantly reduced NF- $\kappa B$ activity in both cell types (Figures 6B, D).

\section{DISCUSSION}

L. acidophilus is a lactic acid producing commensal bacteria found in the gut. It is commonly found in many commercial
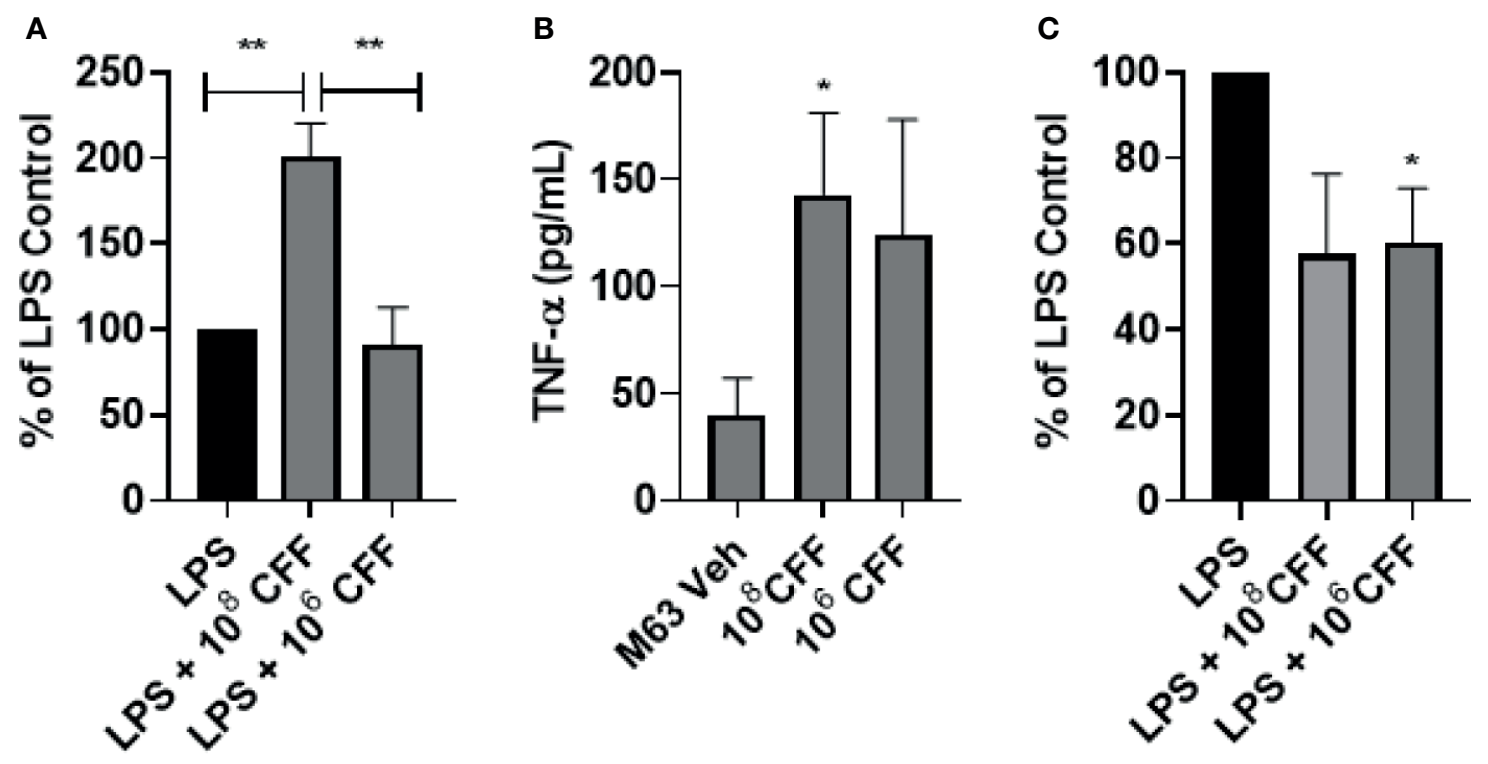

FIGURE 5 | L. acidophilus cell free filtrate (CFF) has concentration-dependent effects on TNF $\alpha$ secretion in THP-1 monocytes and monocyte derived macrophages. THP-1 monocytes or monocyte derived macrophages were incubated with L. acidophilus $10^{8}$ or $10^{6}$ CFF alone or with cells $1 \mathrm{~h}$ after LPS stimulation. Supernatants were obtained $20 \mathrm{~h}$ after incubation and analyzed for levels of TNF $\alpha$ using ELISA. (A) L. acidophilus $10^{8}$ CFF increased TNF $\alpha$ secretion in LPS-stimulated THP-1 monocytes, but $10^{6}$ CFF had no effect. (B) In THP-1 monocyte derived macrophages, L. acidophilus $10^{8}$ CFF alone promoted TNF $\alpha$ production while $10^{6}$ CFF did not significantly alter TNF $\alpha$ production. (C) When THP-1 monocyte derived macrophages were stimulated with $50 \mathrm{ng} / \mathrm{mL}$ LPS $1 \mathrm{~h}$ prior to L. acidophilus CFF treatment, $10^{6} \mathrm{CFF}$ significantly attenuated TNF $\alpha$ production. Data are mean \pm s.e.m. $\%$ of LPS Control data are mean \pm s.e.m. percent change from LPS control adjusted to $100 \%$. ${ }^{*} \mathrm{p}<0.05$, ${ }^{* *} \mathrm{p}<0.01$ compared to controls; THP-1 monocytes $\mathrm{n}=5$ independent experiments; THP-1 monocyte derived macrophages $\mathrm{n}=5$ independent experiments; THP-1 monocyte derived macrophages \% of LPS control $n=4$ independent experiments. 

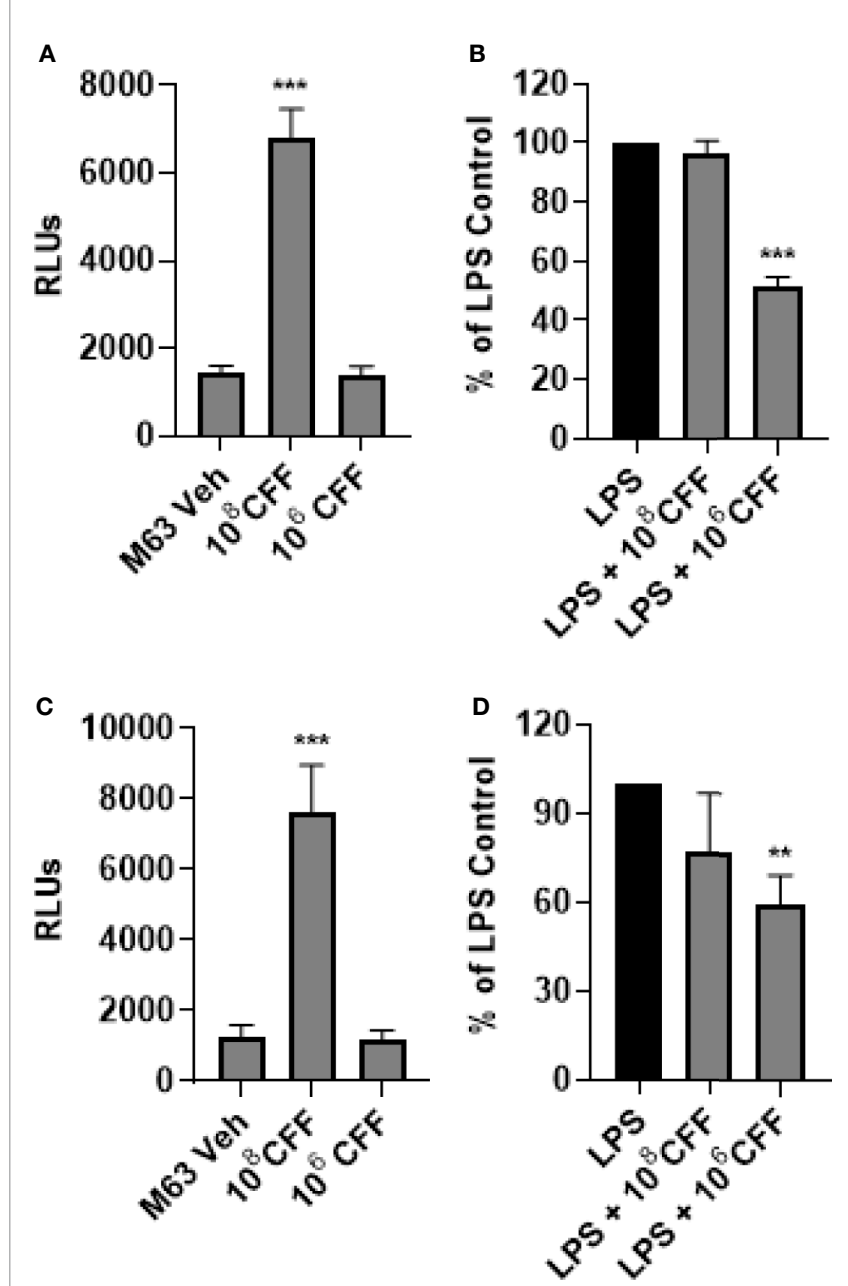

FIGURE 6 | L. acidophilus cell free filtrate (CFF) affects NF-кB activity. Using a luciferase NF-kB reporter THP-1 cell line, monocytes and monocyte derived macrophages were incubated with $L$. acidophilus CFF alone or added $1 \mathrm{~h}$ after LPS stimulation, for $20 \mathrm{~h}$. Luciferase luminescence was measured to quantify NF- $\mathrm{kB}$ activation. (A) In monocytes, $10^{8} \mathrm{CFF}$ alone upregulated NF- $\mathrm{KB}$ activation but $10^{6}$ CFF had no effect. (B) In LPS stimulated monocytes, only $10^{6} \mathrm{CFF}$ reduced NF- $\mathrm{kB}$ activity. (C) $L$. acidophilus $10^{8} \mathrm{CFF}$ increased NF- $\kappa B$ activity in monocyte derived macrophages. (D) Similar to monocytes, only L. acidophilus $10^{6}$ CFF significantly reduced NF-kB activity in monocyte derived macrophages. Data are relative light units (RLUs) or mean \pm s.e.m. percent change from LPS control adjusted to $100 \%$. ${ }^{* \star} \mathrm{p}<0.01,{ }^{\star \star \star} \mathrm{p}<0.001$ compared to appropriate control; monocytes $\mathrm{n}=7$ independent experiments; macrophages $n=8$ independent experiments.

probiotic drinks and yogurt (Kopp-Hoolihan, 2001; Urbanska et al., 2010; Pei et al., 2017; Pu et al., 2017). Within the gut, L. acidophilus poses no serious danger to the host, and in fact has been reported to be important in ensuring that the gut is not overpopulated with potentially pathogenic bacteria (Lievin-Le Moal et al., 2002; Dotan and Rachmilewitz, 2005; Rooks and Garrett, 2016; Plaza-Diaz et al., 2019). As these bacteria live in the luminal border of the gut, it is plausible that their secreted products may regulate both gut bacteria as well as immune cells, including resident macrophages which lie within the gut mucosa and/or monocytes which travel in the blood vessels that supply the gut. In these studies, we show that CFF derived from various concentrations of $L$. acidophilus reduced biofilm formation as well as destroyed established $P$. aeruginosa biofilm. High concentrations of CFF were bactericidal for $P$. aeruginosa but not for E. coli. The CFF also modulated inflammatory responses of monocytes and monocyte derived macrophages. CFF alone did not produce detectable TNF $\alpha$ production in monocytes. High concentration CFF alone stimulated macrophages to produce small amounts of TNF $\alpha$. After LPS stimulation, high concentration CFF stimulated further TNF $\alpha$ production in monocytes. In macrophages, lower concentration CFF reduced LPS-stimulated TNF $\alpha$ production. Using THP-1 cells expressing luciferase under the control of the NF- $\kappa B$ promoter, we show that high concentration CFF increased NF-kB activity in both monocytes and macrophages. Lower concentrations of CFF reduced $\mathrm{NF}-\kappa \mathrm{B}$ activity in LPS stimulated macrophages, suggesting that the low concentration of $\mathrm{CFF}$ reduced production of TNF $\alpha$ by decreasing NF- $\kappa B$ activity.

There are numerous studies in the literature that have shown that various compounds particularly those which inhibit the quorum sensing receptor - LasR (Davies et al., 1998; Savka et al., 2011; Lee and Zhang, 2015) can inhibit virulence. Our studies show however, that quorum sensing inhibition may not be the major mechanism by which $L$. acidophilus reduces $P$. aeruginosa biofilm formation because we show clearly that L. acidophilus CFF not only substantially reduced biofilm formation but also dose-dependently killed $P$. aeruginosa. Therefore it is most plausible that the bactericidal action and/or growth inhibition of $L$. acidophilus CFF is responsible for the reduction in formation of $P$. aeruginosa biofilm over time.

With respect to the growth inhibitory action of the CFF, we show that there was a concentration-dependent effect where high concentration CFF inhibited growth and was bactericidal (> 99.99\% killing) and low concentration CFF caused approximately $30 \%$ growth inhibition. It is important to note that it is not due to acidity per se as $\mathrm{pH}$ matched $\mathrm{HCl}(\mathrm{pH} 4)$ had significantly less growth inhibition than the high concentration CFF. Interestingly, under these conditions, high concentration CFF had a greater inhibitory effect when compared to $1 \mu \mathrm{g} / \mathrm{ml}$ ciprofloxacin. The growth inhibitory effects of L. acidophilus CFF were species specific as it did not inhibit pathogenic E. coli growth to as great an extent and no concentrations used were bactericidal. These results provide good evidence that $L$. acidophilus secretes products that are growth inhibitory and possess some level of specificity. Such properties may be of use as an efficient antimicrobial with less non-specific adverse effects.

Apart from being able to retard biofilm formation, we show that L. acidophilus CFF could also destroy established biofilm. Our results are consistent with the report of (Ramos et al., 2012) which showed that L. plantarum supernatant could partially remove $24 \mathrm{~h}$ established $P$. aeruginosa biofilm after a further 24 h. Those studies however, did not define the "concentration" of the supernatant nor did they examine other concentrations. Our results show that the capacity for L. acidophilus CFF to remove the established biofilm was not due to lowered $\mathrm{pH}$, as $\mathrm{pH}$ matched $\mathrm{HCl}(\mathrm{pH} 4$ or 5 ) did not significantly remove the 
established biofilm. We also performed these experiments after the CFF was heated to $100^{\circ} \mathrm{C}$ for $15 \mathrm{~min}$ and after incubation with Proteinase K. The boiled high concentration CFF retained some of its ability to remove established biofilm but the lower concentration CFF did not have as much anti-biofilm effects as CFF alone, suggesting that a protein may be partially responsible for the effects. Indeed, Lactobacilli secrete bacteriocins, which are protein compounds that possess antimicrobial activities against pathogenic bacteria (Kawai et al., 2000). There are multiple reports that demonstrated that bacteriocins secreted from L. acidophilus inhibit Campylobacter jejuni growth, Serratia marcescens and Bacillus subtilis planktonic and biofilm growth and Candida albicans biofilm (Campana et al., 2012; Vilela et al., 2015; Shahandashti et al., 2016; Sarikhani et al., 2018). The synthesis of bacteriocins is regulated through $L$. acidophilus quorum sensing (Sturme et al., 2007). Specifically, the LuxS/ AI-2 quorum sensing system in gram-positive bacteria promotes the transcription of bacteriocin precursors (Kareb and Aïder, 2020). This lends support to our results showing a clear concentration-dependent effect of CFF. Apart from bacteriocins, the active product(s) within the CFF is unclear but it is thought to be organic acids such as acetic acid, butyric acid and lactic acid (Hamad et al., 2017; Al-alousi et al., 2018; Raheem et al., 2018; Rodrigues et al., 2020). The identity of the active compound(s) in the CFF is a subject of active investigation in the laboratory. Taken together, these studies suggest that there does not need to be cell to biofilm contact for L. acidophilus to remove established biofilm. The mechanism for the destruction of established biofilm is unclear. It is possible that the CFF timedependently damages the structure and adhesiveness of the biofilm. It is unlikely that the primary mechanism of CFF to destroy established biofilm is by killing bacteria encased within the biofilm matrix because if this was the primary mechanism we would see first a lack of effect or a relatively small effect at an early time point $(1 \mathrm{~h})$ as bacteria are being killed before seeing large destruction of biofilm. Instead we observe as early as $1 \mathrm{~h}$ after CFF incubation, $50 \%$ of established biofilm is already removed. This argues against the mechanism for destruction of established biofilm being through the bactericidal action of CFF.

As a functional host defense is critical in the fight to clear bacterial infection, we studied the actions of L. acidophilus CFF on monocyte and macrophage response. Monocytes are circulating mononuclear cells which have four major functions: phagocytosis, inflammatory cytokine production, antigen presentation and differentiation into macrophages after activation and migration into infected tissue (Jacubzick et al., 2017). Macrophages have functions similar to their precursor monocytes but also participate actively in tissue repair. It is important to note that although the inflammatory response is an important part of host defense to clear pathogens, overzealous response may cause tissue injury. In our studies, the CFF appeared to have different effects on monocytes as compared to macrophages. In monocytes, neither concentration of CFF induced detectable amounts of TNF $\alpha$ but after LPS stimulation, high concentration of CFF increased TNF $\alpha$ production further. In monocyte derived macrophages, high concentration CFF alone increased production of TNF $\alpha$ suggesting that CFF is stimulatory. On the other hand, low concentration CFF decreased TNF $\alpha$ production in LPS stimulated cells which suggests that lower concentration CFF is anti-inflammatory. The results with high concentration CFF alone in macrophages are similar to work by Rocha-Ramirez et al. (2017), while anti-inflammatory results of the lower concentration of CFF are consistent with a report by De Marco et al. (2018). Our results provide evidence that the effects of $L$. acidophilus cell-free filtrate are cell and concentration-dependent where high concentrations of CFF which can remove established biofilm, is bactericidal and is stimulatory of monocytes/macrophages while a lower concentration of CFF which was not bactericidal is antiinflammatory. The mechanism for this contrasting and unexpected effect has not been elucidated. We speculate that at low concentrations, an anti-inflammatory bioactive compound(s) within the filtrate are present in sufficient quantity to inhibit NF- $\kappa \mathrm{B}$ in LPS stimulated cells. On the other hand, at high concentrations of filtrate, certain prostimulatory compounds are present in sufficient quantity to overwhelm the effect of anti-stimulatory compounds.

$\mathrm{NF}-\kappa \mathrm{B}$ is a heterodimeric transcription factor that is implicated in the expression of numerous inflammatory mediators including TNF $\alpha$ (Verstrepen et al., 2008; Vallabhapurapu and Karin, 2009; Wang et al., 2014; Tang and Zhu, 2019; Bhardwaj et al., 2020). Our results using NF- $\mathrm{KB}$ reporter THP-1 monocyte-derived macrophages suggest that high concentrations of CFF alone increase TNF $\alpha$ production at least partially by increasing NF- $\kappa \mathrm{B}$ activity. In monocytes however, high concentration of $\mathrm{CFF}$ increased NF- $\kappa$ B activity without any detectable change in TNF $\alpha$ production. Furthermore, in LPS stimulated monocytes, high concentration CFF increased TNF $\alpha$ release further without further increases in NF- $\mathrm{KB}$ activity. Taken together these results suggest that high concentration CFF increases TNF $\alpha$ production only partially by increasing NF- $\kappa \mathrm{B}$ activity and other signaling pathways may be involved (Sabio and Davis 2014). In contrast, our results also suggest that the lower concentration of CFF reduced LPS-stimulated TNF $\alpha$ production in macrophages by decreasing $\mathrm{NF}-\kappa \mathrm{B}$ activity.

In summary, our studies show that different concentrations of L. acidophilus secrete products that inhibit growth, reduce biofilm formation, remove established biofilm and modulate monocyte/macrophage responses. High concentrations of $L$. acidophilus CFF were bactericidal, substantially suppressed biofilm formation, effectively removed established biofilm and were stimulatory in monocyte/macrophages. Low concentration CFF was not bactericidal, but reduced biofilm formation, partially removed established biofilm and was antiinflammatory in macrophages. The studies provide evidence of different properties of specific concentrations of L. acidophilus CFF. We believe more research is warranted to ascertain if different concentrations of $L$. acidophilus CFF can be used in vivo for different and specific conditions. 


\section{DATA AVAILABILITY STATEMENT}

The raw data supporting the conclusions of this article will be made available by the authors, without undue reservation.

\section{AUTHOR CONTRIBUTIONS}

RW performed all experiments and helped write the manuscript. JW helped design studies and write manuscript. KY helped design the studies and was the principal author of the manuscript. All authors contributed to the article and approved the submitted version.

\section{REFERENCES}

Al-alousi, T. I., Abdullah, A. H., and Jasim, M. M. (2018). Prophylactic Role of Lactic Acid Prepared From Lactobacillus Acidophilus on Cryptosporidiosis. Tikrit J. Pure Sci. 23 (8), 38-42. doi: 10.25130/tjps.23.2018.127

Alexandre, Y., Le Berre, R., Barbier, G., and Le Blay, G. (2014). Screening of Lactobacillus Spp. For the Prevention of Pseudomonas Aeruginosa Pulmonary Infections. BMC Microbiol. 14 (107), 1-10. doi: 10.1186/1471-2180-14-107

Angus, D. C., and van der Poll, T. (2013). Severe Sepsis and Septic Shock. N. Engl. J. Med. 369 (21), 2063. doi: 10.1056/NEJMc1312359

Argenta, A., Satish, L., Gallo, P., Liu, F., and Kathju, S. (2016). Local Application of Probiotic Bacteria Prophylaxes Against Sepsis and Death Resulting From Burn Wound Infection. PLoS One 11 (10), e0165294. doi: 10.1371/journal.pone.0165294

Besser, M., Terberger, J., Weber, L., Ghebremedhin, B., Naumova, E. A., Arnold, W. H., et al. (2019). Impact of Probiotics on Pathogen Survival in an Innovative Human Plasma Biofilm Model (hpBIOM). J. Transl. Med. 17 (1), 243. doi: 10.1186/s12967-019-1990-4

Bhardwaj, R., Singh, B. P., Sandhu, N., Singh, N., Kaur, R., Rokana, N., et al. (2020). Probiotic Mediated NF-KappaB Regulation for Prospective Management of Type 2 Diabetes. Mol. Biol. Rep. 47 (3), 2301-2313. doi: 10.1007/s11033-020-05254-4

Bullock, A. J., Garcia, M., Shepherd, J., Rehman, I., and Sheila, M. (2020). Bacteria Induced $\mathrm{pH}$ Changes in Tissue-Engineered Human Skin Detected nonInvasively Using Raman Confocal Spectroscopy. Appl. Spectrosc. Rev. 2, 158171. doi: 10.1080/05704928.2018.1558232

Campana, R., Federici, S., Ciandrini, E., and Baffone, W. (2012). Antagonistic Activity of Lactobacillus Acidophilus ATCC 4356 on the Growth and Adhesion/Invasion Characteristics of Human Campylobacter Jejuni. Curr. Microbiol. 64, 371-378. doi: 10.1007/s00284-012-0080-0

Chen, C. C., Chiu, C. H., Lin, T. Y., Shi, H. N., and Walker, W. A. (2009). Effect of Probiotics Lactobacillus Acidophilus on Citrobacter Rodentium Colitis: The Role of Dendritic Cells. Pediatr. Res. 65 (2), 169-175. doi: 10.1203/PDR.0b013e31818d5a06

Costerton, J. W., Stewart, P. S., and Greenberg, E. P. (1999). Bacterial Biofilms: A Common Cause of Persistent Infections. Science 284 (5418), 1318-1322. doi: $10.1126 /$ science.284.5418.1318

Davies, D. G., Parsek, M. R., Pearson, J. P., Iglewski, B. H., Costerton, J. W., and Greenberg, E. P. (1998). The Involvement of Cell-to-Cell Signals in the Development of a Bacterial Biofilm. Science 280 (5361), 295-298. doi: $10.1126 /$ science.280.5361.295

De Marco, S., Sichetti, M., Muradyan, D., Piccioni, M., Traina, G., Pagiotti, R., et al. (2018). Probiotic Cell-Free Supernatants Exhibited Anti-Inflammatory and Antioxidant Activity on Human Gut Epithelial Cells and Macrophages Stimulated With LPS. Evid. Based Complement. Alternat. Med. 2018, 1756308. doi: 10.1155/2018/1756308

Dodds, D. R. (2017). Antibiotic Resistance: A Current Epilogue. Biochem. Pharmacol. 134, 139-146. doi: 10.1016/j.bcp.2016.12.005

Dotan, I., and Rachmilewitz, D. (2005). Probiotics in Inflammatory Bowel Disease: Possible Mechanisms of Action. Curr. Opin. Gastroenterol. 21 (4), 426-430. doi: 10.1136/pgmj.2005.040899

Gellatly, S. L., and Hancock, R. E. W. (2013). Pseudomonas Aeruginosa: New Insights Into Pathogenesis and Host Defenses. Pathog. Dis. 67, 159-173. doi: $10.1111 / 2049-632 X .1203$

\section{FUNDING}

The studies were supported by NIAID (RO1 AI128202) and the New Jersey Health Foundation (PC84-20).

\section{SUPPLEMENTARY MATERIAL}

The Supplementary Material for this article can be found online at: https://www.frontiersin.org/articles/10.3389/fcimb.2021. 737392/full\#supplementary-material

Hager, C. L., Isham, N., Schrom, K. P., Chandra, J., McCormick, T., Miyagi, M., et al. (2019). Effects of a Novel Probiotic Combination on Pathogenic BacterialFungal Polymicrobial Biofilms. mBio 10 (2), 1-11. doi: 10.1128/mBio.00338-19

Hamad, G. M., Botros, W. A., and Hafez, E. E. (2017). Combination of Probiotic Filtrates as Antibacterial Agent Against Selected Some Pathogenic Bacteria in Milk and Cheese. Int. J. Dairy Sci. 12 (6), 368-376. doi: 10.3923/ ijds.2017.368.376

Han, N., Jia, L., Su, Y., Du, J., Guo, L., Lu, Z., et al. (2019). Lactobacillus Reuteriextracts Promotedwound Healing via PI3K/AKT/ $\beta$-Catenin/Tgf $\beta 1$ Pathway. Stem Cell Res. Ther. 10 (243), 1-11. doi: 10.1186/s13287-019-1324-8

Hotchkiss, R. S., Monneret, G., and Payen, D. (2013). Immunosuppression in Sepsis: A Novel Understanding of the Disorder and a New Therapeutic Approach. Lancet Infect. Dis. 13 (3), 260-268. doi: 10.1016/S1473-3099(13)70001-X

Hotchkiss, C. V., Monneret, G. J., and Payen, P. M. (2017). Monocyte Differentiation and Antigen-Presenting Functions. Nat. Rev. Immunol. 17 (6), 349-362. doi: 10.1038/nri.2017.28

Jakubzick, C. V., Randolph, G. J., and Henson, P. M. (2017). Monocyte Differentiation and Antigen-Presenting Functions. Nat. Rev. Immunol. 17 (6), 349-362. doi: 10.1038/nri.2017.28

Jimenez, P. N., Koch, G., Thompson, J. A., Xavier, K. B., Cool, R. H., and Quax, W. J. (2012). The Multiple Signaling Systems Regulating Virulence in Pseudomonas Aeruginosa. Microbiol. Mol. Biol. Rev. 76 (1), 46-65. doi: 10.1128/MMBR.05007-11

Kareb, O., and Aïder, M. (2020). Quorum Sensing Circuits in the Communicating Mechanismsof Bacteria and Its Implication in the Biosynthesis of Bacteriocinsby Lactic Acid Bacteria: A Review. Probiotics Antimicrob. Proteins 12, 5-17. doi: 10.1007/s12602-019-09555-4

Kawai, Y., Saitoh, B., Takahashi, O., Kitazawa, H., Saito, T., Nakajima, H., et al. (2000). Primary Amino Acid and DNA Sequences of Gassericin T, A Lactacin F-Family Bacteriocin Produced by Lactobacillus Gasseri SBT2055. Biosci. Biotechnol. Biochem. 64 (10), 2201-2208. doi: 10.1271/bbb.64.2201

Khailova, L., Frank, D. N., Dominguez, J. A., and Wischmeyer, P. E. (2013). Probiotic Administration Reduces Mortality and Improves Intestinal Epithelial Homeostasis in Experimental Sepsis. Anesthesiology 119 (1), 166-177. doi: 10.1097/ALN.0b013e318291c2fc

Kopp-Hoolihan, L. (2001). Prophylactic and Therapeutic Uses of Probiotics: A Review. J. Am. Diet Assoc. 101 (2), 229-238; quiz 239-241. doi: 10.1016/S00028223(01)00060-8

Kristian, S. A., Timmer, A. M., Liu, G. Y., Lauth, X., Sal-Man, N., Rosenfeld, Y., et al. (2007). Impairment of Innate Immune Killing Mechanisms by Bacteriostatic Antibiotics. FASEB J. 21 (4), 1107-1116. doi: 10.1096/fj.06$6802 \mathrm{com}$

Lee, J., and Zhang, L. (2015). The Hierarchy Quorum Sensing Network in Pseudomonas Aeruginosa. Protein Cell 6 (1), 26-41. doi: 10.1007/s13238014-0100-x

Lievin-Le Moal, V., Amsellem, R., Servin, A. L., and Coconnier, M. H. (2002). Lactobacillus Acidophilus (Strain LB) From the Resident Adult Human Gastrointestinal Microflora Exerts Activity Against Brush Border Damage Promoted by a Diarrhoeagenic Escherichia Coli in Human Enterocyte-Like Cells. Gut 50 (6), 803-811. doi: 10.1136/gut.50.6.803

Machairas, N., Pistiki, A., Droggiti, D. I., Georgitsi, M., Pelekanos, N., Damoraki, G., et al. (2015). Pre-Treatment With Probiotics Prolongs Survival After 
Experimental Infection by Multidrug-Resistant Pseudomonas Aeruginosa in Rodents: An Effect on Sepsis-Induced Immunosuppression. Int. J. Antimicrob. Agents 45 (4), 376-384. doi: 10.1016/j.ijantimicag.2014.11.013

Maghsood, F., Johari, B., Rohani, M., Madanchi, H., Saltanatpour, Z., and Kadivar, M. (2020). Anti-Proliferative and Anti-Metastatic Potential of High Molecular Weight Secretory Molecules From Probiotic Lactobacillus Reuteri Cell-Free Supernatant Against Human Colon Cancer Stem-Like Cells (HT29 -ShE). Int. J. Pept. Res. Ther. 26, 2619-2631. doi: 10.1007/s10989-020-10049-z

Mattingly, A., Kamatkar, N., Morales Soto, N., Borlee, B., and Shrout, J. (2018). Multiple Environmental Factors Influence the Importance of the Phosphodiesterase DipA Upon Pseudomonas Aeruginosa Swarming. Appl. Environ. Microbiol. 84, 1-15. doi: 10.1128/AEM.02847-17

Moriarty, T. F., Elborn, J. S., and Tunney, M. M. (2007). Effect of $\mathrm{pH}$ on the Antimicrobial Susceptibility of Planktonic and Biofilm-Grown Clinical Pseudomonas Aeruginosa Isolates. Br. J. BioMed. Sci. 64 (3), 101-104. doi: 10.1080/09674845.2007.11732766

Musafer, H. K., Kuchma, S. L., Naimie, A. A., Schwartzman, J. D., Al-Mathkhury, H. J. F., and O'Toole, G. A. (2014). Investigating the Link Between Imipenem Resistance and Biofilm Formation by Pseudomonas Aeruginosa. Microb. Ecol. 68, 111-120. doi: 10.1007/s00248-013-0361-6

Pei, R., Martin, D. A., DiMarco, D. M., and Bolling, B. W. (2017). Evidence for the Effects of Yogurt on Gut Health and Obesity. Crit. Rev. Food Sci. Nutr. 57, 1569-1583. doi: 10.1080/10408398.2014.883356

Plaza-Diaz, J., Ruiz-Ojeda, F. J., Gil-Campos, M., and Gil, A. (2019). Mechanisms of Action of Probiotics. Adv. Nutr. 10 (suppl_1), S49-S66. doi: 10.1093/ advances/nmy063

Pu, F., Guo, Y., Li, M., Zhu, H., Wang, S., Shen, X., et al. (2017). Yogurt Supplemented With Probiotics Can Protect the Healthy Elderly From Respiratory Infections: A Randomized Controlled Open-Label Trial. Clin. Interv. Aging 12, 1223-1231. doi: 10.2147/CIA.S141518

Quintieri, L., Fanelli, F., Zuhlke, D., Caputo, L., Logrieco, A. F., Albrecht, D., et al. (2020). Biofilm and Pathogenesis-Related Proteins in the Foodborne P. Fluorescens ITEM 17298 With Distinctive Phenotypes During Cold Storage. Front. Microbiol. 11, 991. doi: 10.3389/fmicb.2020.00991

Raheem, A., Liang, L., Zhang, G., and Cui, S. (2018). Prophylactic Role of Lactic Acid Prepared From Lactobacillus Acidophilus on Cryptosporidiosis. Front. Immunol. 12, 616713. doi: 10.3389/fimmu.2021.616713

Ramos, A. N., Sesto Cabral, M. E., Noseda, D., Bosch, A., Yantorno, O. M., and Valdez, J. C. (2012). Antipathogenic Properties of Lactobacillus Plantarum on Pseudomonas Aeruginosa: The Potential Use of its Supernatants in the Treatment of Infected Chronic Wounds. Wound Repair Regen. 20 (4), 552562. doi: 10.1111/j.1524-475X.2012.00798.x

Rocha-Ramirez, L. M., Perez-Solano, R. A., Castanon-Alonso, S. L., Moreno Guerrero, S. S., Ramirez Pacheco, A., Garcia Garibay, M., et al. (2017). Probiotic Lactobacillus Strains Stimulate the Inflammatory Response and Activate Human Macrophages. J. Immunol. Res. 2017, 4607491. doi: 10.1155/ 2017/4607491

Rodrigues, J. Z. S., Passos, M. R., Silva de Macedo Neres, N., Almeida, R. S., Pita, L. S., Santos, I. A., et al. (2020). Antimicrobial Activity of Lactobacillus Fermentum TcUESC01 Against Streptococcus Mutans UA159. Microb. Pathog. 142, 104063. doi: 10.1016/j.micpath.2020.104063

Rooks, M. G., and Garrett, W. S. (2016). Gut Microbiota, Metabolites and Host Immunity. Nat. Rev. Immunol. 16 (6), 341-352. doi: 10.1038/nri.2016.42

Sabio, G., and Davis, R. J. (2014). TNF and MAP Kinase Signalling Pathways. Semin Immunol. 26 (3), 237-245. doi: 10.1016/j.smim.2014.02.009

Sarikhani, M., Kermanshahi, R. K., Ghadam, P., and Gharavi, S. (2018). The Role of Probiotic Lactobacillus Acidophilus ATCC 4356 Bacteriocin on Effect of HBsu on Planktonic Cells and Biofilm Formation of Bacillus Subtilis. Int. J. Biol. Macromol. 115, 762-766. doi: 10.1016/j.ijbiomac.2018.03.087

Savka, M. A., Le, P. T., and Burr, T. J. (2011). LasR Receptor for Detection of LongChain Quorum-Sensing Signals: Identification of N-Acyl-Homoserine Lactones Encoded by the avsI Locus of Agrobacterium Vitis. Curr. Microbiol. 62 (1), 101-110. doi: 10.1007/s00284-010-9679-1

Shahandashti, R. V., Kermanshahi, R. K., and Ghadam, P. (2016). The Inhibitory Effect of Bacteriocin Produced by Lactobacillus Acidophilus ATCC 4356 and Lactobacillus Plantarum ATCC 8014 on Planktonic Cells and Biofilms of Serratia Marcescens. Turkish J. Med. Sci. 46, 1188-1196. doi: 10.3906/sag-1505-51
Sturme, M. H. J., Francke, C., Siezen, R. J., de Vos, W. M., and Kleerebezem, M. (2007). Making Sense of Quorum Sensing in Lactobacilli: A Special Focus on Lactobacillus Plantarum WCFS1. Microbiol. (Reading) 153 (Pt 12), 3939-3947. doi: 10.1099/mic.0.2007/012831-0

Tang, C., and Zhu, G. (2019). Classic and Novel Signaling Pathways Involved in Cancer: Targeting the NF-kappaB and Syk Signaling Pathways. Curr. Stem Cell Res. Ther. 14 (3), 219-225. doi: 10.2174/1574888X13666180723104340

Thornton, J. M., Walker, J. M., Sundarasivarao, P. Y. K., Spur, B. W., Rodriguez, A., and Yin, K. (2021). Lipoxin A4 Promotes Reduction and Antibiotic Efficacy Against Pseudomonas Aeruginosa Biofilm. Prostaglandins Other Lipid Mediat. 152, 106505. doi: 10.1016/j.prostaglandins.2020.106505

Tram, G., Korolik, V., and Day, C. J. (2013). MBDS Solvent: An Improved Method for Assessment of Biofilms. Adv. Microbiol. 3 (2), 200-204. doi: 10.4236/ aim.2013.32030

Urbanska, A. M., Paul, A., Bhathena, J., and Prakash, S. (2010). Suppression of Tumorigenesis: Modulation of Inflammatory Cytokines by Oral Administration of Microencapsulated Probiotic Yogurt Formulation. Int. J. Inflamm. 2010, 894972. doi: 10.4061/2010/894972

Vallabhapurapu, S., and Karin, M. (2009). Regulation and Function of NF-kappaB Transcription Factors in the Immune System. Annu. Rev. Immunol. 27, 693733. doi: 10.1146/annurev.immunol.021908.132641

Verstrepen, L., Bekaert, T., Chau, T. L., Tavernier, J., Chariot, A., and Beyaert, R. (2008). TLR-4, IL-1R and TNF-R Signaling to NF-Kappab: Variations on a Common Theme. Cell. Mol. Life Sci. 65, 2964-2978. doi: 10.1007/s00018-0088064-8

Vilela, S. F., Barbosa, J. O., Rossoni, R. D., Santos, J. D., Prata, M. C., Anbinder, A. L., et al. (2015). Lactobacillus Acidophilus ATCC 4356 Inhibits Biofilm Formation by C. Albicans and Attenuates the Experimental Candidiasis in Galleria Mellonella. Virulence 6 (1), 29-39. doi: 10.4161/21505594.2014.981486

Wang, N., Liang, H., and Zen, K. (2014). Molecular Mechanisms That Influence the Macrophage M1-M2 Polarization Balance. Front. Immunol. 5, 614. doi: $10.3389 /$ fimmu.2014.00614

Wang, Y., Xie, Q., Zhang, Y., Ma, W., Ning, K., Xiang, J. Y., et al. (2020). Combination of Probiotics With Different Functions Alleviate DSS-Induced Colitis by Regulating Intestinal Microbiota, IL-10, and Barrier Function. Appl. Microbiol. Biotechnol. 104 (1), 335-349. doi: 10.1007/s00253-019-10259-6

Wijesinghe, G., Dilhari, A., Gayani, B., Kottegoda, N., Samaranayake, L., and Weerasekera, M. (2019). Influence of Laboratory Culture Media on In Vitro Growth, Adhesion, and Biofilm Formation of Pseudomonas Aeruginosa and Staphylococcus Aureus. Med. Princ. Pract. 28 (1), 28-35. doi: 10.1159/ 000494757

Zheng, J., Wittouck, S., Salvetti, E., Franz, C. M. A. P., Harris, H. M. B., Mattarelli, P., et al. (2020). A Taxonomic Note on the Genus Lactobacillus: Description of 23 Novel Genera, Emended Description of the Genus Lactobacillus Beijerinck 1901, and Union of Lactobacillaceaeand Leuconostocaceae. Int. J. Syst. Evol. Microbiol. 70, 2782-2858. doi: 10.1099/ijsem.0.004107

Zolkiewicz, J., Marzec, A., Ruszczynski, M., and Feleszko, W. (2020). Postbiotics-A Step Beyond Pre- and Probiotics. Nutrients 12 (8), 1-17. doi: 10.3390/ nu12082189

Conflict of Interest: The authors declare that the research was conducted in the absence of any commercial or financial relationships that could be construed as a potential conflict of interest.

Publisher's Note: All claims expressed in this article are solely those of the authors and do not necessarily represent those of their affiliated organizations, or those of the publisher, the editors and the reviewers. Any product that may be evaluated in this article, or claim that may be made by its manufacturer, is not guaranteed or endorsed by the publisher.

Copyright $\odot 2021$ Wilson, Walker and Yin. This is an open-access article distributed under the terms of the Creative Commons Attribution License (CC BY). The use, distribution or reproduction in other forums is permitted, provided the original author(s) and the copyright owner(s) are credited and that the original publication in this journal is cited, in accordance with accepted academic practice. No use, distribution or reproduction is permitted which does not comply with these terms. 